\title{
KEBEBASAN BEREKSPRESI DALAM PERSPEKTIF HAK ASASI MANUSIA: PERLINDUNGAN, PERMASALAHAN DAN IMPLEMENTASINYA DI PROVINSI JAWA BARAT
}

\author{
Tony Yuri Rahmanto \\ Badan Penelitian dan Pengembangan Hukum dan HAM \\ Kementerian Hukum dan HAM RI \\ JI. H.R. Rasuna Said Kav. 4-5, Kuningan Jakarta Selatan 12940 \\ Email : tonyscooterist@gmail.com
}

Tulisan Diterima: 18-03-2016 Direvisi: 11-04-2016 Disetujui: 17-07-2016

\begin{abstract}
Abstrak
Proses demokratisasi di Indonesia saat ini menempatkan publik sebagai pemilik dan pengendali utama ranah penyiaran. Namun permasalahan utama dalam penyiaran di negeri ini adalah tidak konsistennya kebijakan pemerintah sebagai salah satu regulator penyiaran, lemahnya lembaga regulator pengawas penyiaran dan ketidaktaatan penyelenggara penyiaran. Jawa Barat dengan budaya yang beragam telah memiliki lembaga penyiaran, namun pada praktiknya di lapangan belum menampilkan keberagaman isi siaran dan keberagaman kepemilikan. Oleh karena itu persoalannya adalah bagaimanakah implementasi Undang-Undang Nomor 32 Tahun 2002 tentang Penyiaran memberikan perlindungan hak kebebasan berekspresi masyarakat khususnya di Jawa Barat. Metode penelitian ini menggunakan pendekatan kualitatif serta menganalisa substansi, konteks, dan relasi antara lembaga penyiaran, pemerintah daerah serta masyarakat dilihat dari aspek Hak Asasi Manusia. Hasil penelitian menunjukkan bahwa berlakunya Undang-Undang Nomor 32 Tahun 2002 tentang Penyiaran belum sepenuhnya memberikan jaminan perlindungan terhadap hak kebebasan berekespresi yang dimiliki pemerintah, lembaga penyiaran serta masyarakat di Provinsi Jawa Barat, masih ditemukan permasalahan terkait keberagaman isi siaran, sentralisasi kepemilikan lembaga penyiaran, kurangnya pemanfaatan lembaga penyiaran publik dan teguran serta sanksi yang diberikan seringkali diabaikan oleh para pelaku penyiaran.
\end{abstract}

Kata Kunci: Kebebasan Berekspresi, Regulasi, Hak Asasi Manusia.

\begin{abstract}
Democratization process in Indonesia is currently putting the public as the owner and the ultimate controller in broadcasting sphere. The main problem in Indonesia is the inconsistent governments policy as one of broadcasting regulators, the weak regulatory of monitoring agencies and the disobedient broadcasting operators. West Java as one of the provinces that has cultural diversity have a brodcasting operator, in practice, they do not present the diversity of broadcast content and diversity of ownership. The question is how the implementation of Law No. 32 of 2002 on Broadcasting in terms of protecting the freedom of expression, especially in West Java. This research applies qualitative approach, conducted analysis of the substance, context and relationships between broadcasters, local governments and community from a human rights perspective. The result shows that the enactment of Law No. 32 of 2002 on Broadcasting has not fully guarantee the protection of the right to freedom of expression owned by the government, broadcasters and communities in West Java province, other problems are related to: the diversity of broadcast content, centralization of ownership of broadcaster, the lack of utilization of public broadcasters, and the reprimands and sanctions are often overlooked by the broadcasters.
\end{abstract}

Keywords: Freedom of Expression, Regulation, Human Rights. 


\section{PENDAHULUAN}

\section{Latar Belakang}

Hak Asasi Manusia merupakan hak dasar yang secara kodrati melekat pada diri manusia, Hak Asasi Manusia bersifat universal dan langgeng, sehingga harus dihormati, dilindungi dan dipenuhi serta tidak boleh diabaikan, dikurangi atau dirampas oleh siapapun. Tugas penghormatan, perlindungan dan pemenuhan HAM selain kewajiban dan tanggung jawab pemerintah, dibutuhkan juga peran dan partisipasi dari masyarakat.

Jika berbicara mengenai kebebasan berekspresi yang merupakan hak dari setiap manusia, amanat dari Undang-Undang Dasar Negara Republik Indonesia Tahun 1945, khususnya pasal 28F (amandemen ke-2, yang ditetapkan pada Agustus 2000) menyatakan bahwa "Setiap orang berhak untuk berkomunikasi dan memperoleh informasi untuk mengembangkan pribadi dan lingkungan sosialnya, serta berhak untuk mencari, memperoleh, memiliki, menyimpan, mengolah, dan menyampaikan informasi dengan menggunakan segala jenis saluran yang tersedia". Undang-Undang Nomor 39 Tahun 1999 tentang Hak Asasi Manusia pada pasal 14 ayat (2) menyatakan bahwa "Setiap orang berhak untuk mencari, memperoleh, memiliki, menyimpan, mengolah, dan menyampaikan informasi dengan menggunakan segala jenis sarana yang tersedia". Selain itu Kovenan Internasional tentang Hak Sipil dan Politik yang terdapat pada pasal 19 ayat (2) juga mengatakan bahwa "Setiap orang berhak atas kebebasan berekspresi; hak ini termasuk kebebasan untuk mencari, menerima dan memberikan informasi dan ide/gagasan apapun, terlepas dari pembatasan-pembatasan, baik secara lisan, tulisan, cetakan, dalam bentuk karya seni atau melalui media lain sesuai dengan pilihannya". ${ }^{3}$

Kemudian pada tataran implementasi di lapangan, hak kebebasan berekspresi bagi

$1 \quad$ Undang-Undang Dasar Negara Republik Indonesia tahun 1945

2 Undang-Undang Nomor 39 Tahun 1999 tentang Hak Asasi Manusia

3 Kovenan Internasional tentang Hak-Hak Sipil dan Politik Tahun 1966 masyarakat salah satunya diatur melalui Undang-Undang Nomor 32 Tahun 2002 tentang Penyiaran, namun hampir enam tahun sejak digulirkan pada 2010, pembahasan revisi Undang-Undang Penyiaran Nomor 32 tahun 2002 hingga sekarang masih dalam pembahasan di DPR. Di tahun 2016 ini, Komisi I DPR RI menyatakan akan menuntaskan pembahasan revisi undang-undang tersebut menjadi UndangUndang Penyiaran baru. ${ }^{4}$ Terasa segar dalam ingatan kita pada lima belas tahun yang lalu, ketika pro dan kontra mewarnai pengesahan Rancangan Undang-Undang (RUU) Penyiaran menjadi Undang-Undang Penyiaran. Pihak yang kontra meyakini bahwa RUU Penyiaran merupakan bentuk baru dominasi pemerintah terhadap lembaga-lembaga penyiaran di Indonesia. Pendapat sebaliknya berkeyakinan bahwa hadirnya Undang-Undang Penyiaran justru mampu menjamin demokratisasi penyiaran berlangsung baik di tanah air Indonesia. Bukan tidak mungkin, realitas yang sama akan terjadi ketika DPR RI merencanakan revisi undangundang tersebut pada saat ini.

Berdasarkan Undang-Undang Nomor 32 Tahun2002tentang Penyiaran, terdapatbeberapa prinsip dasar pengelolaan media penyiaran yang mencakup keterbukaan akses, partisipasi, serta perlindungan dan kontrol publik, diversity of ownership (keberagaman kepemilikan), dan diversity of content (keberagaman isi). ${ }^{5}$ Fakta yang terjadi, masyarakat pada saat ini dapat mengakses dan menerima informasi melalui berbagai macam media penyiaran setiap hari selama 24 jam. Namun, pada hakikatnya kemudahan terhadap akses informasi yang diperoleh masyarakat adalah semu serta informasi yang diperoleh belum tentu bernilai positif.

Provinsi Jawa Barat memiliki cakupan wilayah yang luas dan merupakan salah satu provinsi di Indonesia yang memiliki keanekaragaman kesenian dan kebudayaan. Namun fakta di

4 Diskusi revisi Undang-Undang Penyiaran: Penguatan KPI dalam UU Penyiaran Baru, http:// www.kpi.go.id/index.php/component/blog_ calendar/2016/02? Itemid= $($ diakses 11 Maret 2016 $)$

5 UU No. 32 Tahun 2002: Produk Hukum yang Inkonsistensi terhadap Demokrsi, http://mountainpirates.blogspot.com/2014/12/uu-penyiaran-no322002-produk-hukum.html (diakses 3 November 2015) 
lapangan menunjukkan keanekaragaman kesenian dan kebudayaan yang dimiliki provinsi tersebut belum banyak dikenal masyarakat Indonesia ataupun masyarakat internasional. Oleh karenanya media penyiaran dapat berperan penting untuk menanggapi hal tersebut dimana tidak hanya menampilkan hiburan semata tetapi dapat menampilkan seluruh kearifan lokal yang dimiliki oleh bangsa Indonesia. Dengan spirit otonomi daerah, dampak kehadiran televisi lokal merupakan warna baru dunia penyiaran tanah air karena selama ini kearifan lokal kurang optimal diangkat dalam wujud audio visual. ${ }^{6}$ Publik menaruh harapan sangat tinggi terhadap televisi lokal. Kehadirannya di dunia penyiaran diharapkan dapat memberi alternatif tontonan dan dapat mengakomodasi khazanah lokalitas yang saat ini kurang tertampung dalam tayangan televisi. ${ }^{7}$ Paket tayangan yang bermaterikan sosial, budaya, pariwisata, ekonomi, dan unsur kedaerahan menjadi suatu kebutuhan bagi seluruh lapisan masyarakat dalam upaya optimalisasi pembangunan daerah. Sehingga kehadiran televisi lokal, menjadi solusi penting untuk hal tersebut. ${ }^{8}$

Berdasarkan hal tersebut, ada dua isu strategis yang harusnya menjadi perhatian. Pertama, masalah lembaga regulator pengatur lembaga penyiaran, dan kedua adalah masalah kewenangan dalam mengatur kepemilikan media. Masyarakat sebagai publik diharapkan dapat mengawal semua perkembangan ini sehingga pada saat proses revisi yang dilakukan oleh pemerintah tetap memperhatikan kepentingan publik yang luas. Masyarakat tidak perlu terkagetkaget bila nantinya Undang-Undang Penyiaran versi revisi ini akhirnya disahkan karena luput dari pencermatan jika kita sebagai publik tidak saling mengawasi dan mengingatkan.

6 Dedeh Fardiah, "Peluang dan Tantangan Membangun Media Penyiaran Berbasis Kearifan Lokal di Jawa Barat". Makalah dipublikasikan dan diunduh melalui http://www.google.co.id/url?sa=t\& $r c t=j \& q=\& e s r c=s \&$ source $=$ web\& $c d=4 \& c a d=r j a \& u a$ $\mathrm{ct}=\quad 8 \&$ ved $=0$ ahUKEwjmsfGVt9vJAhXOkI4KHYZrA HcQFgg0MAM\&url=http\%3A\%2F\%2Fkomunikasi. unsoed.ac.id\% 2Fsites\%2Fdefault\%2Ffiles\%2F15. DEDEHFARDIAH_unisba.pdf\&usg=AFQjCNFpG_w vOk68kMx4Me5nfumCHwAHOA\&bvm=bv.109910 813,d.c2E (diakses 7 November 2015) (diakses 7 November 2015) hlm. 217.

$7 \quad$ Ibid. hlm. 215.

$8 \quad$ Ibid.hlm. 217.

\section{Rumusan Masalah}

Untukmenindaklanjutipermasalahantentang penyiaran yang dimaksud maka permasalahan yang diangkat yaitu bagaimanakah implementasi Undang-Undang Nomor 32 Tahun 2002 tentang Penyiaran memberikan perlindungan hak kebebasan berekspresi masyarakat khususnya di Provinsi Jawa Barat.

\section{Tujuan}

Tujuan dari penelitian ini adalah untuk mendapatkan gambaran tentang implementasi Undang-Undang Nomor 32 Tahun 2002 tentang Penyiaran dalam memberikan perlindungan hak kebebasan berekspresi masyarakat Provinsi Jawa Barat. Sementara manfaat yang diharapkan dari penelitian ini adalah dapat digunakan sebagai bahan rekomendasi dalam membuat rumusan kebijakan yang berkaitan dengan implementasi Undang-Undang Nomor 32 Tahun 2002 tentang Penyiaran terhadap perlindungan hak kebebasan berekspresi bagi masyarakat.

\section{Metodologi Penelitian}

Penelitian ini menggunakan metode penelitian hukum normatif empiris, sifat penelitian bersifat deskriptif analisis dengan pendekatan kualitatif. Pengumpulan data primer dilakukan dengan wawancara, sedangkan data sekunder diperoleh dari bahan-bahan kepustakaan berupa bahan hukum primer yaitu norma dasar, bahan hukum terkodifikasi serta peraturan perundang-undangan yang kemudian dianalisis secara kualitatif dengan mendiskripsikan data lapangan yang diperoleh kemudian mereduksi segala informasi yang diperoleh untuk memfokuskan pada masalah utama. Lokasi penelitian dilaksanakan di Provinsi Jawa Barat dengan justifikasi pertama, bahwa belum semua lembaga penyiaran menampilkan keragaman isi siaran (kurangnya siaran kearifan dan khasanah lokalitas); kedua, masih adanya dualisme pemberian ijin/rekomendasi alokasi frekuensi (Postel dan Dishub); dan ketiga, masih dominannya kepemilikan frekuensi oleh lembaga penyiaran nasional sehingga kecil peluang bagi muncul dan berkembangnya lembaga penyiaran lokal. ${ }^{9}$

9 Laporan Kunjungan Kerja Komisi I DPR RI pada reses masa persidangan III Tahun sidang 2005-2006 ke Provinsi Jawa Barat tanggal 27-30 Maret 2006 


\section{PEMBAHASAN}

\section{Konspetualisasi Kebebasan Berekspresi}

Everett M. Rogers (1986) sebagaimana dikutip Nasrullah, mencatat tentang empat fase perkembangan komunikasi manusia, yaitu: fase the writing era, fase the printing era, fase the telecommunication era, dan interactive communication era. ${ }^{10}$ Dari keempat fase tersebut penulis menduga bahwa telah terlahir yang namanya kebebasan berpendapat dan kebebasan berekspresi.

Kebebasan berekspresi merupakan salah satu elemen penting dalam demokrasi. Bahkan, dalam sidang pertama PBB pada tahun 1946, sebelum disahkannya Universal Declaration on Human Rights atau traktat-traktat diadopsi, Majelis Umum PBB melalui Resolusi Nomor 59 (I) terlebih dahulu telah menyatakan bahwa "hak atas informasi merupakan hak asasi manusia fundamentaldan...standardarisemua kebebasan yang dinyatakan 'suci' oleh PBB'. Kebebasan berekspresi merupakan salah satu syarat penting yang memungkinkan berlangsungnya demokrasi dan partisipasi publik dalam setiap pembuatan kebijakan. Warga negara tidak dapat melaksanakan haknya secara efektif dalam pemungutan suara atau berpartisipasi dalam pembuatan kebijakan publik apabila mereka tidak memiliki kebebasan untuk mendapatkan informasi dan mengeluarkan pendapatnya serta tidak mampu untuk menyatakan pandangannya secara bebas.

Pertanyaan mendasar terkait hal tersebut adalah apa sebenarnya kebebasan berekspresi itu. Para sarjana berpendapat, salah satunya seperti dikemukakan oleh John Locke, bahwa kebebasan bereskpresi adalah cara untuk pencarian kebenaran. Kebebasan berekspresi ditempatkan sebagai kebebasan untuk mencari, menyebarluaskan dan menerima informasi serta kemudian memperbincangkannya apakah mendukung atau mengkritiknya sebagai sebuah proses untuk menghapus miskonsepsi kita atas fakta dan nilai. ${ }^{11}$ John Stuart Mill mengatakan,

10 Rusli Nasrullah, Komunikasi Antar-Budaya di Era Budaya Siber, (Jakarta: Kencana Perdana Media Group, 2012), hlm. 4.

11 Larry Alexander, Is There A Right to Freedom of Expression, (New York: Cambridge University Press, 2005), hlm. 128. kebebasan berekspresi dibutuhkan untuk melindungi warga dari penguasa yang korup dan tiran. $^{12}$ Suatu pemerintahan yang demokratis mensyaratkan warganya dapat menilai kinerja pemerintahannya. Dalam memenuhi kebutuhan kontrol dan penilaian itulah warga semestinya memiliki semua informasi yang diperlukan tentang pemerintahnya. Tidak sebatas itu, syarat berikutnya warga dapat menyebarluaskan informasi tersebut, dan kemudian mendiskusikannya antara satu dengan yang lainnya. ${ }^{13}$

Berangkat dari sandaran teori tersebut, kebebasan bereskpresi kemudian menjadi sebuah klaim untuk melawan penguasa yang melarangnya atau pun menghambat pelaksanaanya untuk mendapatkan kebebasan berekspresi. ${ }^{14}$ Seperti dikemukakan di awal, kebebasan bereskpresi memiliki dimensi politik, bahwa kebebasan ini dianggap sebagai elemen esensial bagi keikutsertaan warga dalam kehidupan politik dan juga mendorong gagasan kritis dan perdebatan tentang kehidupan politik bahkan sampai soal kewenangan militer.

Kaitan kebebasan bereskpresi dengan demokrasi kemudian diakui dalam hukum internasional hakasasimanusiayangmenyatakan bahwa kebebasan berekspresi merupakan pra-syarat terwujudnya prinsip transparansi dan akuntabilitas yang pada akhirnya sangat esensial bagi pemajuan dan perlindungan hak asasi manusia. Kebebasan bereskpresi juga menjadi pintu bagi dinikmatinya kebebasan berkumpul, berserikat dan pelaksanaan hak untuk memilih. ${ }^{15}$.

Beberapa titik penting muncul, di mana batas itu, siapa yang menetapkan dan apa konsekuensi yang harus ditanggung bila

12 John Stuart Mill, On Liberty, Chapter II, Of The Liberty on Thought and Discussion, 1859, http://www. utilitarianism.com/ol/two.html, lihat juga Chin Liew Ten, dalam Mill on Liberty, Chapter Eight: Freedom of Expression, dalam http://www.victorianweb.org/ philosophy/mill/ten/ch8.html. (diakses 8 November 2015)

13 Lihat Larry Alexander, dalam Op. Cit., hal. 136.

14 Vincenzo Zeno-Zencovich, Freedom of Expression: A Critical and Comparative Analysis, (New York: Routledge-Cavendish, 2008), hal. 1.

15 ICCPR/C/GC/34, Article 19: Freedoms of Opinion and Expression, Human Rights Committee, 102nd session, Geneva, 11-29 July 2011, paragraf 3-4. 
pembatasan itu tidak dilaksanakan, juga tentunya landasan apa yang paling sah untuk menetapkan pembatasan. ${ }^{16}$ Kovenan sendiri mengakui bahwa kebebasan bereskpresi menerbitkan "kewajiban dan tanggung jawab khusus". Oleh karena itu kebebasan berekspresi dikenai pembatasan yang diberi syarat harus ditetapkan berdasar hukum dan sesuai dengan kebutuhan dengan alasan "menghormati hak atau nama baik orang lain" dan "melindungi keamanan nasional atau ketertiban umum atau kesehatan atau moral masyarakat". ${ }^{17}$

Pembatasan ini muncul dari tugas dan tanggung jawab khusus yang melekat pada pelaksanaan kebebasan tersebut. Dari pelbagai instrumen HAM internasional hanya ICCPR (International Covenant on Civil and Political Right) yang berbicara tentang pembatasan ini. Terdapat tiga syarat yang ditetapkan dalam Pasal 18 dan 19 ICCPR yang harus terpenuhi sebelum pembatasan terhadap hak atas kebebasan berekspresi dilakukan, yakni: (1) harus diatur menurut hukum; (2) harus untuk suatu tujuan yang sah/memiliki legitimasi; (3) harus dianggap perlu untuk dilakukan (proporsional). Terkait dengan syarat yang ke-2, pembatasan hanya dapat dilakukan untuk tujuan "melindungi keamanan, ketertiban, kesehatan atau moral masyarakat atau hak dan kebebasan dasar orang lain" (Pasal 18) atau untuk "menghormati hak dan reputasi orang lain atau untuk melindungi keamanan nasional atau ketertiban umum, atau kesehatan atau moral masyarakat" (Pasal 19).

\section{Keragaman Media Melalui Undang-Undang Penyiaran}

Berkenaan dengan judul penelitian, isu yang menarik terkait dengan Undang-Undang Penyiaran saat ini dan belum mendapatkan penyelesaiannya ialah mengenai topik keberagaman media baik itu kepemilikan ataupun keberagaman dari isi siaran, di mana hal tersebut merupakan isu penting bagi kebebasan berekspresi dalam hukum internasional. Isu ini mengemuka dan menjadirelevan, oleh karenanya negara harus membuat suatu cara untuk melindungi pengguna media termasuk kelompok

16 Vincenzo Zeno-Zencovich, Freedom ... Loc. Cit., hal.2.

17 Pasal 19 Kovenan Internasional Hak-hak Sipil dan Politik. minoritas agar dapat menerima gagasan dan informasi yang ada. Selain itu perkembangan media massa modern juga meminta negara agar mencegah adanya monopoli dan menjamin adanya keberagaman media sehingga tercipta demokratisasi di bidang penyiaran.

Dalam sepuluh tahun terakhir, globalisasi sudah terjadi bahkan sampai ke Indonesia. Dalam proses tersebut, banyak sekali budayabudaya luar yang masuk ke Indonesia, yang mana sebagian besar dipengaruhi oleh budaya barat. Hingga saat ini, terjadi pergeseran budaya yang mengakibatkan terkikisnya budaya asli Indonesia oleh budaya-budaya asing. Inilah yang merupakan titikawal dari banyaknya siaran-siaran yang lebih mementingkan keuntungan dari suatu program siaran, bukan kualitas program siaran tersebut. ${ }^{18}$ Teknologi komunikasi modern pada prinsipnya ingin menyampaikan nilai, perspektif dan ide kepada orang dari berbagai budaya, kelas sosial dan usia di seluruh dunia. Namun yang menjadi kekhawatiran adalah anak-anak kecil yang merupakan pengguna media yang paling antusias. ${ }^{19}$

Pada dasarnya kebijakan penyiaran merupakan hasil interaksi antara kepentingan industri, negara dan masyarakat yang terus menerus mengalami perubahan sesuai dengan kekuatan (power) yang berkembang. ${ }^{20}$ Namun hal yang demikian perlu adanya suatu kontrol dan pengawasan oleh negara agar tidak terjadi penyimpangan dalam pelaksanaannya. Oleh karenanya, lembaga yang berwenang dalam pengawasan di bidang penyiaran yang telah ditetapkan oleh Undang-Undang adalah Komisi Penyiaran Indonesia (KPI) dan Komisi Penyiaran Indonesia Daerah (KPID) di tingkat Provinsi.

Walaupun telah ada lembaga yang berwenang untukmengawasi kegiatan penyiaran, pada implementasinya masih sering ditemukan isi

18 Biro Kajian dan AdvokasiMahasiswa BEM FH Unpad Kabinet Harmoni, "Mempertanyakan sikap KPI Terhadap Tayangan-Tayangan di Televisi Masa Kini" http://www.hukumpedia.com/bemfhunpad/ mempertanyakan-sikap-kpi-terhadap-tayangantayangan-di-televisi-masa-kini (diakses 12 November 2015)

19 James Lull, Media Komunikasi Budaya Suatu Pendekatan Global, (Jakarta: Yayasan Obor Indonesia, 1998), hlm. 15.

20 Redi Panuju, Sistem Komunikasi Indonesia, (Yogyakarta: Pustaka Pelajar, 1997), hIm. 4. 
siaran yang tidak sesuai dengan nilai-nilai moral masyarakat Indonesia, sehingga yang menjadi masalah adalah sampai dimana KPI dan KPID memiliki kewenangan atas hal tersebut, karena pada kenyataannya saat ini masih banyak pihak khusunya lembaga penyiaran swasta yang tetap melanggar teguran dan sanksi yang diberikan KPI dan KPID dalam menyiarkan suatu tayangan. Oleh karenanya kewenangan KPI dan KPID harus diperjelas dan diperkuat sehingga tidak ada lagi pihak-pihak penyiaran yang melakukan pelanggaran. Dengan diperjelas artinya tidak hanya memberikan teguran dalam bentuk tertulis saja tetapi dalam bentuk penghentian isi siaran hingga pencabutan ijin siaran.

KPI dan KPID harus dapat membuat jera pelanggar yang menyalahi aturan, dengan lebih berani untuk memberikan sanksi selain hanya teguran. Hal tersebut diatur dalam Pasal 74 Peraturan Komisi Penyiaran Indonesia Nomor 3 tahun 2007 tentang Standar Program Siaran, yang merupakan peraturan pelaksana dari dari Undang-Undang Nomor 32 tahun 2002 tentang Penyiaran.

\section{Implementasi Undang-Undang Penyiaran di Provinsi Jawa Barat}

tentang

Kenyataan di lapangan khususnya di Jawa Barat, menunjukkan bahwa Undang-Undang Nomor 32 Tahun 2002 tentang Penyiaran belum sepenuhnya memberikan jaminan kepastian dalam perlindungan hak kebebasan berekspresi bagi masyarakat di Provinsi Jawa Barat. Berdasarkan hasil wawancara dengan narasumberdapatdijelaskanbahwaimplementasi tersebut hanya sebatas pada pemberian ruang atau tempat kepada masyarakat untuk bebas dalam berpendapat dan berekspresi namun bagi para pelaku penyiaran, hak kebebasan berekspresi belum sepenuhnya didapatkan. Selain itu dari keberagaman isi siaran, hal tersebut masih belum tercapai di Provinsi Jawa Barat.

Menurut informasi dari KPID Provinsi Jawa Barat terkait keberagaman isi siaran juga belum sepenuhnya tercapai, implementasi di lapangan menunjukkan bahwa isi siaran masih dilakukan oleh lembaga penyiaran swasta nasional yang berkedudukan di pusat, sehingga apabila ada permasalahan yang berkaitan dengan isi siaran penanganannya langsung oleh KPI Pusat sementara KPID Provinsi Jawa Barathanya dapat memberikan rekomendasi untuk menindaklanjuti temuan. Tetapi apabila pelanggaran di lakukan di Provinsi Jawa Barat, maka KPID langsung menindak lanjuti berdasarkan laporan dari masyarakat. Proses tindak lanjut dilakukan dengan cara pertama, KPID bersama-sama masyarakat pelapor mengadakan suatu diskusi terarah untuk membahas terkait indikasi temuan yang ada di lapangan. Kedua, KPID mendengar masukan ataupun aduan dari masyarakat terkait pelanggaran yang dilakukan oleh lembaga penyiaran. Ketiga, KPID Provinsi memberikan teguran kepada lembaga penyiaran yang melanggar aturan yang sudah dibuat berdasarkan Undang-Undang Penyiaran. Apabila teguran tersebut tidak ditanggapi maka KPID melanjutkannya kepada imbauan, jika belum mendapat respon maka KPID melakukan klarifikasi,. dan apabila tidak ditanggapi juga maka KPID membuat suatu rekomendasi untuk melakukan penghentian isi siaran.

Permasalahan lain dalam penyiaran di Indonesia khususnya di Jawa Barat yaitu ketidaktaatan penyelenggara penyiaran yang dilakukan oleh lembaga penyiaran yang disebabkan ketidaktaatan pada regulasi utama media penyiaran, yaitu pengabaian terhadap Undang Undang nomor 32 tahun 2002 tentang Penyiaran yang sudah berlangsung selama satu dekade.

\section{Peluang dan Tantangan}

Kebebasan bisnis media yang berkembang tanpa kendali membuat ranah penyiaran kita kehilangan asas keadilan, pemerataan, etika, sekaligus keberagaman. Hal yang demikian sebenarnya sudah dijelaskan dalam pasal 18, pasal 20, dan pasal 34 ayat (4) Undang Undang Nomor 32 tahun 2002 tentang Penyiaran serta Peraturan Pemerintah No 50 tahun 2005 pasal 34 ayat (1) huruf (a) tentang Lembaga Penyiaran Swasta. Selain itu Undang-Undang Penyiaran juga mengatur penyertaan modal asing dalam usaha penyiaran dibatasi maksimum 20\%, kendati kenyataannya sudah seringkali dilanggar. Pasal-pasal tersebut pada intinya melarang seseorang atau badan hukum memiliki dan atau menguasai lebih dari satu lembaga penyiaran swasta di satu daerah. Selain melarang konsentrasi kepemilikan, Undang-Undang Penyiaran juga melarang pemindahtanganan izin penyelenggaraan siaran-dalam arti dijual 
atau dialihkan kepada badan hukum lain. Sanksi terhadap pelanggaran itu ialah pidana penjara (2-5 tahun), denda 500 juta sampai 10 milyar, serta pencabutan izin penyiaran.

Penulis menganalisa bahwa perlunya penguatan pada regulasi media. Regulasi media memiliki pengertian yaitu aturan-aturan dan kebijakan yang berkaitan dengan yang mengatur hubungan dan operasional media massa. Regulasi sangat penting bagi keteraturan dan keseimbangan hubungan media baik dengan pemerintah, masyarakat, sesama industri media dan global media. Akan tetapi hal tersebut tidak jarang dianggap sebagai suatu aturan yang bersifat membatasi, adanya kontrol penuh oleh negara, dan bahkan dianggap sebagai penghalang atas kebebasan berekspresi. Namun, harus diakui bahwa regulasi media sangat diperlukan dalam situasi tertentu. Berikut tiga alasan pentingnya penguatan pada regulasi media. Pertama, regulasi media membantu audience (masyarakat) untuk mendapatkan informasi sesuai dengan tuntutan dan kualitas tertentu. Kedua, regulasi mempunyai sisi di mana menjaga aturan pasar agar tidak terciptanya monopoli atau bahkan komersialisasi dari media. Ketiga, regulasi bukanlah sebagai sarana dari kaum mayoritas untuk mendominasi kaum minoritas. Berdasarkan 3 alasan tersebut, regulasi justru tetap dapat menjunjung tinggi nilai kebebasan berekspresi setiap individu serta penghormatan hak asasi manusia dan bahkan dapat memaksa mayoritas untuk tetap mau membuka diri terhadap kritik atas penyimpangan yang telah dilakukan. Hal tersebut dilakukan demi mewujudkan prinsip pluralitas di Indonesia.

Regulasi yang dimaksud dalam hal ini pada dasarnya sudah dimiliki oleh Indonesia melalui Undang-Undang Nomor 32 Tahun 2002 tentang Penyiaran, hanya saja pada praktiknya di lapangan masih terdapat penyimpangan yang dilakukan oleh segelintir kelompok. Provinsi Jawa Barat pada umumnya tidak terlalu mempermasalahkan hal tersebut karena menurut data dari KPID Provinsi Jawa Barat dapat diketahui bahwa terdapat 515 lembaga penyiaran yang beroperasi di Provinsi Jawa Barat yang terdiri dari lembaga penyiaran publik (televisi dan radio), lembaga penyiaran swasta (televisi, televisi digital dan radio), lembaga penyiaran komunitas (televisi dan radio), dan lembaga penyiaran berlangganan (televisi). ${ }^{21}$

Kendala lain terkait lembaga penyiaran di Provinsi Jawa Barat adalah keberadaan lembaga penyiaran publik yang diwakili oleh TVRI dan RRI yang tidak diperhatikan. Kurangnya pemanfaatan lembaga penyiaran publik yang dilakukan oleh pemerintah daerah dalam mensosialisasikan program kerja dan kebijakannya Pada dasarnya fungsi dari lembaga penyiaran publik adalah untuk memberikan informasi yang bersifat netral dan tidak memihak serta filter dari setiap lembaga penyiaran yang ada di Indonesia dan diharapkan penyampaiannya kepada masyarakat juga bersifat netral. Oleh karena itu perlunya dibentuk suatu aturan lain untuk memperkuat posisi dari lembaga penyiaran publik tersebut.

Permasalahan lain yang tidak kalah penting yaitu terdapat beberapa kerancuan pasal dalam Undang-Undang Nomor 32 tahun 2002. Pasal yang menyinggung mengenai kepemilikian televisi sebagai lembaga penyiaran, yaitu pasal 5 ayat (7) yang menyatakan mencegah monopoli kepemilikan dan mendukung persaingan yang sehat di bidang penyiaran" dan pasal 18 ayat 1 "Pemusatan kepemilikan dan penguasaan Lembaga Penyiaran Swasta oleh satu orang atau satu badan hukum, baik di satu wilayah siaran maupun di beberapa wilayah siaran, dibatasi". Kedua pasal ini saling bertentangan dan ambigu satu sama lain, dalam pasal 5 tertulis "mencegah monopoli" tetapi yang tertulis dalam pasal 18 terkesan membiarkan adanya kepemilikan lembaga penyiaran swasta oleh satu orang saja (monopoli), terbukti dalam pasal tersebut hanya tercantum kata "dibatasi", bukan "dilarang".

Terlepas dari semua itu, pemerintah pada dasarnya telah beritikad baik untuk mengontrol kebebasan media massa di Indonesia tanpa mengurangi kebebasan media massa itu sendiri. Walau bagaimanapun, kebebasan media massa harus menjadi kebebasan yang bertanggung jawab. Namun adanya pemanfaatan celah yang belum diatur dan belum tercantum/dibahas dalam undang-undang juga perlu dicermati dengan seksama karena membuat para pihak yang memahami hal tersebut dapat melakukan banyak hal sekehendak hati.

21 Data dari Komisi Penyiaran Indonesia Daerah (KPID) Provinsi Jawa Barat 


\section{PENUTUP}

\section{Kesimpulan}

Berdasarkan hasil analisis data penelitian, kesimpulanyangmenjadiprioritas, yaitu: Pertama, Undang-Undang Nomor 32 Tahun 2002 tentang Penyiaran belum sepenuhnya memberikan jaminan perlindungan terhadap hak kebebasan berekespresi masyarakat di Provinsi Jawa Barat karena masih belum adanya keberagaman isi siaran yang dilakukan oleh lembaga penyiaran, sentralisasi kepemilikan lembaga penyiaran yang mengakibatkan adanya monopoli dalam dunia penyiaran, serta kurangnya pemanfaatan lembaga penyiaran publik yang sudah tersedia untuk dimanfaatkan oleh pemerintah daerah serta masyarakat Provinsi Jawa Barat. Kedua, sanksi dan teguran dari Komisi Penyiaran Indonesia Daerah (KPID) Provinsi Jawa Barat sebagai lembaga regulator penyiaran di daerah seyogyanya harus diikuti dengan kepastian bahwa pelanggaran yang terjadi tidak akan terulang kembali oleh lembaga penyiaran. Hal ini harus sangat diperhatikan dengan terang dan jelas demi kebaikan masyarakat terkait isi siaran. Ketiga, keberagaman kepemilikan media yang terjadi di Provinsi Jawa Barat masih belum sesuai dengan apa yang diamanatkan oleh Undang-Undang Nomor 32 Tahun 2002 tentang Penyiaran. Fakta di lapangan menemukan bahwa masih adanya kepemilikan lembaga penyiaran yang ada di Provinsi Jawa Barat yang tetap dimiliki oleh lembaga penyiaran yang berkedudukan di Jakarta atau dengan kata lain merupakan cabang dari lembaga penyiaran yang berkedudukan di pusat. Sehingga isi dari siaran tetap berasal dari pusat.

\section{Saran}

Berdasarkan kesimpulan dari hasil analisis data penelitian, maka sejumlah opsi kebijakan yang dapat penulis sampaikan dalam konteks perbaikan Undang-Undang Nomor 32 Tahun 2002 tentang Penyiaran adalah Pemerintah Daerah Provinsi Jawa Barat dapat meningkatkan peran dalam perlindungan hak kebebasan berekspresi bagi masyarakat Jawa Barat, peran ini dapat dilakukan antara lain: Pertama, dari jalur regulasi, pemerintah daerah dapat memberikan rekomendasi terkait revisi undang-undang tentang Penyiaran dalam hal peningkatan peran dari lembaga regulator lembaga penyiaran, penegasan sanksi serta penegasan pasal terkait keberagaman kepemilikan lembaga penyiaran sehingga tidak terjadi sentralisasi kepemilikan. Kedua, perlunya pemberdayaan lembaga penyiaran publik sebagai institusi penguat kebangsaan, sebagai contoh yaitu mendiseminasikan hasil-hasil kebijakan Gubernur ataupun Walikota dengan memanfaatkan lembaga penyiaran publik karena cakupan wilayah dari lembaga tersebut sangat luas dan segala lapisan masyarakat dapat menerima hal tersebut dengan baik karena lembaga penyiaran publik dianggap sebagai lembaga yang merepresentasikan masyarakat. Ketiga, Pemerintah Daerah Provinsi Jawa Barat perlu melakukan sinergitas kepada pelaku (lembaga penyiaran, owner, dan pekerja di bidang penyiaran) serta masyarakat melalui keterbukaan akses, partisipasi, perlindungan dan kontrol publik, diversity of ownership (keberagaman kepemilikan), dan diversity of content (keberagaman isi) menurut Undang-Undang Nomor 32 Tahun 2002 tentang Penyiaran. Hal tersebut dapat dilakukan melalui Focus Group Discussion (FGD), seminar, atau dapat berupa pelatihan-pelatihan yang bertahap hingga membagikan soft file dalam bentuk file maupun audio visual.

\section{DAFTAR PUSTAKA}

\section{Buku}

Alexander, Larry. Is There A Right to Freedom of Expression, (New York: Cambridge University Press, 2005).

Lull, James. Media Komunikasi Budaya Suatu Pendekatan Global, (Jakarta: Yayasan Obor Indonesia, 1998).

Nasrullah, Rusli. Komunikasi Antar-Budaya di Era Budaya Siber, (Jakarta: Kencana Perdana Media Group, 2012).

Panuju, Redi Sistem Komunikasi Indonesia, (Yogyakarta: Pustaka Pelajar, 1997), hlm.4.

Zeno-Zencovich, Vincenzo. Freedom of Expression: A Critical and Comparative Analysis, (New York: Routledge-Cavendish, 2008). 
Laporan

ICCPR/C/GC/34, Article 19: Freedoms of Opinion and Expression, Human Rights Committee, 102nd session, Geneva, 11-29 July 2011, paragraf 3-4.

Laporan Kunjungan Kerja Komisi I DPR RI pada reses masa persidangan III Tahun sidang 2005-2006 ke Provinsi Jawa Barat tanggal 27-30 Maret 2006

\section{Website}

UU No. 32 Tahun 2002: Produk Hukum yang Inkonsistensi terhadap Demokrsi, http:// mountain-pirates. blogspot.com/2014/12/uupenyiaran-no-322002-produk-hukum.html (diakses 3 November 2015)

Dedeh Fardiah, "Peluang dan Tantangan Membangun Media Penyiaran Berbasis Kearifan Lokal di Jawa Barat". Makalah dipublikasikan dan diunduh melalui http://www.google. co.. id/url ? sa $=\mathrm{t} \& \mathrm{rct}=\mathrm{j} \& \mathrm{q}=\&$ esrc $=\mathrm{s} \&$ source $=$ web $\& c d=4 \& c a d=$ rja $\&$ uact $=8 \&$ ved $=0$ ah UKEwjmsfGVt9vJAhXOkI4KHYZrAHcQ Fgg0MAM\&url=http\%3A\%2F\%2Fkomun ikasi.unsoed.ac.id\%2Fsites $\% 2$ Fdefault $\%$ 2Ffiles\%2F15.DEDEHFARDIAH_unisba. pdf\&usg=AFQjCNFpG_wvOk68kMx4Me5n fumCHwAHOA\&bvm=bv.109910813,d.c2E (diakses 7 November 2015) hlm. 217.

John Stuart Mill, On Liberty, Chapter II, Of The Liberty on Thought and Discussion, 1859, http://www.utilitarianism.com/ol/ two.html, lihat juga Chin Liew Ten, dalam Mill on Liberty, Chapter Eight: Freedom of Expression, dalamhttp://www.victorianweb. org/philosophy/mill/ten/ch8.html. (diakses 8 November 2015)

Biro Kajian dan AdvokasiMahasiswa BEM FH Unpad Kabinet Harmoni, "Mempertanyakan sikap KPI Terhadap Tayangan-Tayangan di Televisi Masa Kini" http://www.hukumpedia. com/bemfhunpad/mempertanyakan-sikapkpi-terhadap-tayangan-tayangan-di-televisimasa-kini (diakses 12 November 2015)

Diskusi revisi Undang-Undang Penyiaran: Penguatan KPI dalam UU Penyiaran Baru,http://www.kpi.go.id/index.php/ component $/$ blog_calendar $/ 2016 / 02$ ?temid= (diakses 11 Maret 2016)

\section{Peraturan Perundang-undangan}

Undang-Undang Dasar Negara Republik Indonesia tahun 1945

Undang-Undang Nomor 39 Tahun 1999 tentang Hak Asasi Manusia

Kovenan Internasional tentang Hak-Hak Sipil dan Politik Tahun 1966

Undang-Undang Nomor 32 Tahun 2002 tentang Penyiaran 


